STUDIA I PRACE WYDZIAKU NAUK EKONOMICZNYCH I ZARZĄDZANIA NR 39, t. 1

DOI:10.18276/sip.2015.39/1-10

\author{
Karolina Beyer* \\ Uniwersytet Szczeciński
}

\title{
WARTOŚĆ KAPITAŁU INTELEKTUALNEGO SPÓŁEK NOTOWANYCH NA WIG 30
}

\begin{abstract}
Streszczenie
Celem artykułu jest zaprezentowanie wyników pomiaru kapitału intelektualnego przedsiębiorstw notowanych na warszawskiej Giełdzie Papierów Wartościowych w ramach indeksu WIG 30 w okresie 2009-2012. Wartość kapitału intelektualnego badanych podmiotów została określona przy wykorzystaniu koncepcji wskazującej kapitał intelektualny jako różnicę między wartością rynkową a wartością księgową przedsiębiorstw. Efektem badań jest określenie wartości kapitału intelektualnego badanych przedsiębiorstw oraz zbadanie, w jakim stopniu kapitał intelektualny wpływa na wartość rynkową podmiotów. Pomiar zaprezentowany w artykule pozwala na porównanie wartości kapitału intelektualnego między badanymi przedsiębiorstwami oraz stanowi narzędzie do monitorowania zachodzących tendencji zmian jego wartości w czasie. Zaprezentowane wyniki badań stanowią część realizowanego projektu badawczego finansowanego ze środków Narodowego Centrum Nauki przyznanych na podstawie decyzji numer DEC-2011/01/N/HS4/06036.
\end{abstract}

Słowa kluczowe: kapitał intelektualny, pomiar kapitału intelektualnego, MV-BV, WIG 30

*Adres e-mail: kbeyer@univ.szczecin.pl. 


\section{Wprowadzenie}

Pojęcie kapitału intelektualnego wzbudza szerokie zainteresowanie zarówno wśród teoretyków, jak i praktyków biznesu. Sukces współczesnych przedsiębiorstw funkcjonujących w trudnych warunkach rynkowych uzależniony jest od odpowiedniego wykorzystania posiadanych zasobów wyróżniających firmę na tle konkurencji. Zasoby te muszą charakteryzować się unikalnością, elastycznością, jak i trudnością do imitacji przez konkurentów. Wymienione kluczowe cechy zasobów przedsiębiorstwa zapewnić może posiadany przez przedsiębiorstwa kapitał intelektualny. Z racji faktu, iż kapitał intelektualny tworzą przeważnie zasoby o charakterze niematerialnym, to zarządzanie jego elementami, a tym samym ich pomiar jest niezwykle trudny.

Podstawowa koncepcja kapitału intelektualnego opiera się na założeniu, iż stanowi on nadwyżkę ponad księgową wartością przedsiębiorstwa, którą inwestorzy na rynku skłonni są za przedsiębiorstwo zapłacić. Ponadto, im przedsiębiorstwo jest bardziej zaawansowane technologicznie, im więcej środków przeznacza na działalność badawczo-rozwojową i im sprawniej powiększa zasoby wiedzy, tym inwestorzy wyceniają takie przedsiębiorstwo wyżej. W związku z powyższym inwestorzy bardziej cenią przedsiębiorstwa oparte na wiedzy i oczekują wyższych zysków z posiadania ich akcji. Pogłębiająca się różnica między wartością rynkową a wartością materialnego majątku przedsiębiorstw z biegiem lat jest coraz większa. W wielu przypadkach wartość majątku stanowi niewielki procent wartości, jaką przedsiębiorstwo osiąga na rynku. Należy podkreślić, iż o ile w przypadku przedsiębiorstw opartych na kapitale materialnym i finansowym różnica pomiędzy wartością rynkową a księgową utrzymuje się na stałym poziomie, to w przypadku przedsiębiorstw opartych na kapitale intelektualnym różnica ta rośnie ${ }^{1}$.

$\mathrm{W}$ tym miejscu pojawia się pytanie, jak mierzyć te niematerialne zasoby przedsiębiorstwa. Podstawowa trudność wyboru odpowiednich narzędzi do badania i pomiaru kapitału intelektualnego wynika właśnie z jego niematerialnego charakteru. Należy również podkreślić, że przeważająca liczba dostępnych metod opisujących kapitał intelektualny ma charakter jakościowy², a wiele elementów kapitału intelek-

1 W.M. Fruin, Knowledge Works: Managing in Intellectual Capital at Toshiba, Oxford University Press, New York 1997; L. Edvinsson, M.S. Malone, Kapitat intelektualny, Wydawnictwo Naukowe PWN, Warszawa 2001, s. 100.

2 Kompleksowa metoda Nawigator Skandii, monitor aktywów niematerialnych czy broker technologii to jedne $\mathrm{z}$ wielu metod jakościowego pomiaru kapitału intelektualnego. 
tualnego nie jest możliwa do kwantyfikacji i prezentacji w wartościach pieniężnych, jak na przykład wiedza i doświadczenie ${ }^{3}$.

Opracowane metody pomiaru kapitału intelektualnego mogą dostarczać informacji ilościowej lub jakościowej, mogą być przeznaczone na potrzeby wewnętrzne lub do prezentacji zewnętrznej, mogą dotyczyć poszczególnych elementów kapitału intelektualnego lub określać go jako całość, mogą być proste w kwantyfikacji lub opierać się na skomplikowanych obliczeniach i wielu wskaźnikach, mogą wykorzystywać powszechnie dostępne dane lub bazować na informacjach dostępnych jedynie w ramach badanego przedsiębiorstwa ${ }^{4}$.

Próbę usystematyzowania metod pomiaru kapitału intelektualnego podjął K.E. Sveiby, dzieląc je na cztery kategories:

1. Metody kapitalizacji rynkowej (Market Capitalization Methods-MCM).

2. Metody bezpośredniego pomiaru kapitału intelektualnego (Direct Intellectual Capital Methods - DIC).

3. Metody oparte na zwrocie z aktywów (Return on Assets Methods - ROA).

4. Metody kart punktowych (Scorecard Methods - SC).

W niniejszym artykule zaprezentowano wyniki stanowiące część szerszych badań nad kapitałem intelektualnym polskich przedsiębiorstw realizowanych $\mathrm{w}$ ramach projektu badawczego finansowanego ze środków Narodowego Centrum Nauki przyznanych na podstawie decyzji numer DEC-2011/01/N/HS4/06036. W tekście przedstawiono wyniki pomiaru kapitału intelektualnego jedną z metod kapitalizacji rynkowej określającej wartość kapitału intelektualnego jako różnicę między wartością rynkową przedsiębiorstwa a jego wartością księgową.

\section{MV - BV jako metoda kapitalizacji rynkowej}

Pomiar kapitału intelektualnego oparty na różnicy między wartością rynkową a wartością księgową zaliczany jest do metod bazujących na kapitalizacji rynkowej.

3 S. Kasiewicz, W. Rogowski, M. Kicińska, Kapitat intelektualny, spojrzenie z perspektywy interesariuszy, Oficyna Ekonomiczna, Kraków 2006, s. 101.

4 K. Beyer, Problematyka pomiaru kapitatu intelektualnego, w: Wycena przedsiębiorstw, zarzadzanie wartościa, zarządzanie ryzykiem, red. D. Zarzecki, Zeszyty Naukowe Uniwersytetu Szczecińskiego 2013, nr 761, „Finanse. Rynki Finansowe. Ubezpieczenia” nr 60, s. 605.

5 K.E. Sveiby, Methods for Measuring Intangible Assets, www.sveiby.com/articles/IntangibleMethods.htm (8.02.2014). 
Pomiar tą metodą ma na celu zaprezentowanie kapitału intelektualnego w wartościach pieniężnych. Należy podkreślić zalety wartościowania kapitału intelektualnego w ten sposób. Po pierwsze, zastosowanie tej metody jest szybkie i nieskomplikowanie. Po drugie, dostęp do danych niezbędnych do obliczeń jest łatwy, szczególnie w przypadku spółek notowanych na giełdzie. Niestety, z używaniem tej metody jako miarodajnego narzędzia wyceny kapitału intelektualnego wiążą się również pewne wątpliwości. Podstawowym problemem jest stosowanie tej metody w przedsiębiorstwach nienotowanych na giełdzie, w których pojawia się problem z właściwym określeniem wartości rynkowej. Inną wątpliwość stanowi sposób określania wartości księgowej. Najczęściej wartość ta obliczana jest jako wartość księgowa aktywów netto, tj. suma aktywów przedsiębiorstwa pomniejszona o księgową wartość kapitałów obcych. Z drugiej strony, wartość rynkowa może być wrażliwa na czynniki, które leżą poza możliwością kontroli przez przedsiębiorstwa (spekulacje, zdarzenia przypadkowe, sezonowe itp.). W literaturze tematu zarzuca się również tej metodzie, iż w związku z wyceną kapitału intelektualnego opierającą się na różnicy między wartością rynkową a księgową przedsiębiorstwa powoduje, że wewnętrzna polityka rachunkowości może decydować o wartości kapitału intelektualnego ${ }^{6}$.

W dalszej części artykułu zaprezentowano wycinek przeprowadzonych badań mających na celu określenie wartości kapitału intelektualnego w przedsiębiorstwach notowanych na Giełdzie Papierów Wartościowych w Warszawie w ramach indeksu WIG 30.

\section{Wartość kapitału intelektualnego przedsiębiorstw notowanych na WIG 30}

Celem przeprowadzonego badania było określenie wartości kapitału intelektualnego trzydziestu największych podmiotów notowanych na warszawskim parkiecie. Zaprezentowane wyniki obejmują lata 2009-2012 i stanowią podstawę do podjęcia dalszych prób pomiaru kapitału intelektualnego w polskich przedsiębiorstwach.

Wartość kapitału intelektualnego określona została jako różnica pomiędzy wartością rynkową a wartością księgową badanego przedsiębiorstwa. W tabeli 1 za-

6 P.N. Bukh, H.T. Larsen, J. Mouritsen, Constructing Intellectual Capital Statements, „Scandinavian Journal of Management" 2001, No. 17, s. 87-108. 
prezentowana została wartość kapitału intelektualnego badanych przedsiębiorstw. Analizowane spółki zostały uszeregowane według prowadzonej działalności.

Kolorem szarym w tabeli 1 zaznaczone zostały wyniki $\mathrm{z}$ wartością ujemną. Oznacza to, że wartość księgowa w tych przypadkach jest wyższa niż wartość rynkowa danego przedsiębiorstwa. Dokonując analizy wyników zaprezentowanych w tabeli 1, można stwierdzić, że wartość kapitału intelektualnego badanych spółek jest bardzo zróżnicowana. Ponadto, zauważa się, iż na poziom kapitału intelektualnego duży wpływ ma rodzaj prowadzonej działalności. Najniższe wyniki osiągane są przez spółki należące do sektora energetycznego oraz paliwowego. Wyniki te wskazują, iż w tych sektorach prawidłowością jest duży udział majątku materialnego (rzeczowego) w wartości rynkowej. Fakt ten związany jest ze specyfiką przedsiębiorstw paliwowych i energetycznych i polega na konieczności posiadania dużej liczby ogniw łańcucha wartości w ramach tych przedsiębiorstw. Pięć spółek, co stanowi $17 \%$ badanych przedsiębiorstw, wykazuje ujemną wartość kapitału intelektualnego w całym badanym okresie (Azoty Tarnów, LOTOS, Orlen, Netia, Asseco).

Na uwagę zasługuje fakt, że przedsiębiorstwa jak Asseco (informatyka) oraz Netia (telekomunikacja), których działalność zaliczyć można do sektora nowoczesnych technologii, osiągają wyniki ujemne, co przy założeniu użytego wskaźnika świadczy o braku posiadanego kapitału intelektualnego. W przypadku spółki Asseco wartość majątku w badanym okresie jest średnio dwukrotnie wyższa od wartości, jaką spółka ta osiąga na rynku. Natomiast wartość księgowa Netii jest o ok. 25\% wyższa od kwoty wyceny rynkowej. Uzyskane wyniki w tych spółkach są odmienne od oczekiwanych, gdyż z założenia wartość przedsiębiorstw informatycznych i telekomunikacyjnych generowana jest przez zasoby o charakterze niematerialnym, ze szczególnym uwzględnieniem wiedzy zatrudnionego kapitału ludzkiego. Wśród przedsiębiorstw telekomunikacyjnych badana została również spółka Orange (do 2013 pod nazwą Telekomunikacja Polska SA). W odróżnieniu do konkurencyjnej Netii Orange w całym badanym okresie wykazuje posiadanie kapitału intelektualnego, którego wartość od 2009 do 2011 r. wzrosła prawie dwukrotnie, natomiast w 2012 r. wartość ta spadła do poziomu 3,9 mld zł, co jest wartością niższą niż osiągnięta w 2009 r. 
Tabela 1. Wartość kapitału intelektualnego przedsiębiorstw notowanych w ramach indeksu WIG 30 w latach 2009-2012 w mln zl

\begin{tabular}{|c|c|c|c|c|c|}
\hline Lp. & Spółka & 2009 & 2010 & 2011 & 2012 \\
\hline 1 & PGE & 3537,45 & 5676,98 & $-2409,56$ & $-6623,47$ \\
\hline 2 & Tauron & & $-4695,27$ & $-6711,08$ & $-8403,62$ \\
\hline 3 & Enea & 74,24 & 585,72 & $-2533,80$ & $-3994,40$ \\
\hline 4 & Orange (TP) & 4643,75 & 7203,86 & 8679,23 & 3376,99 \\
\hline 5 & Netia & $-118,72$ & $-272,36$ & $-424,88$ & $-643,01$ \\
\hline 6 & Eurocash & 1733,37 & 3089,41 & 3391,45 & 5249,23 \\
\hline 7 & $\mathrm{CCC}$ & 1526,03 & 2188,35 & 1309,72 & 2274,49 \\
\hline 8 & LPP & 2059,57 & 3006,48 & 2612,35 & 6891,81 \\
\hline 9 & Asseco & $-54,72$ & $-2096,25$ & $-3027,39$ & $-3460,54$ \\
\hline 10 & Cyfrowy Polsat & 3326,81 & 3999,42 & 2806,72 & 3248,07 \\
\hline 11 & TVN & 3579,74 & 4615,57 & 2618,46 & 2052,19 \\
\hline 12 & Orlen & $-7186,49$ & $-4650,88$ & $-12299,66$ & $-7135,23$ \\
\hline 13 & Grupa Lotos & $-2993,77$ & $-2792,58$ & $-4756,33$ & $-3711,66$ \\
\hline 14 & PGNiG & 925,67 & $-2456,47$ & $-1146,00$ & 3492,00 \\
\hline 15 & Jastrzębska Spółka Węglowa & & & 1430,95 & 2274,94 \\
\hline 16 & Lubelski Węgiel Bogdanka & 308,03 & 1772,48 & 1391,37 & 2329,47 \\
\hline 17 & KGHM & 10624,66 & 19708,22 & $-1270,19$ & 16290,03 \\
\hline 18 & Synthos & $-117,84$ & 1930,86 & 2883,74 & 4230,67 \\
\hline 19 & Azoty Tarnów & $-530,85$ & $-671,78$ & $-1821,72$ & $-34,88$ \\
\hline 20 & Kernel & 1739,04 & 3451,54 & 1588,93 & 1348,36 \\
\hline 21 & Boryszew & $-8,58$ & 1635,25 & 207,92 & 140,82 \\
\hline 22 & mBank (BRE Bank) & 3448,48 & 5717,06 & 2293,52 & 4120,03 \\
\hline 23 & BZWBK & 7847,97 & 8930,46 & 9385,14 & 9077,13 \\
\hline 24 & HANDLOWY & 2946,78 & 5723,74 & 2427,31 & 5452,42 \\
\hline 25 & PEKAO & 24032,76 & 26704,20 & 15703,84 & 20504,95 \\
\hline 26 & PKO & 27064,13 & 32827,93 & 17328,02 & 21417,35 \\
\hline 27 & Alior & & & & 1737,12 \\
\hline 28 & ING Bank Śląski & 5267,97 & 5983,99 & 3818,66 & 3704,40 \\
\hline 29 & $\mathrm{PZU}$ & & 17898,32 & 13813,36 & 23466,69 \\
\hline 30 & Globe Trade Centre & 1474,64 & 1183,07 & $-285,61$ & 100,13 \\
\hline
\end{tabular}

Źródło: opracowanie własne. 
Wśród badanych przedsiębiorstw najwyższe wartości kapitału intelektualnego osiągają spółki prowadzące działalność finansową: banki PKO BP i PEKAO SA oraz ubezpieczyciel PZU. Zestawienie dziesięciu spółek z najwyższą wartością kapitału intelektualnego w podziale na lata 2009-2012 prezentuje rysunek 1.

Rysunek 1. Przedsiębiorstwa o najwyższym kapitale intelektualnym w latach 2009-2012 (w mln zł)

\section{KI w 2009}
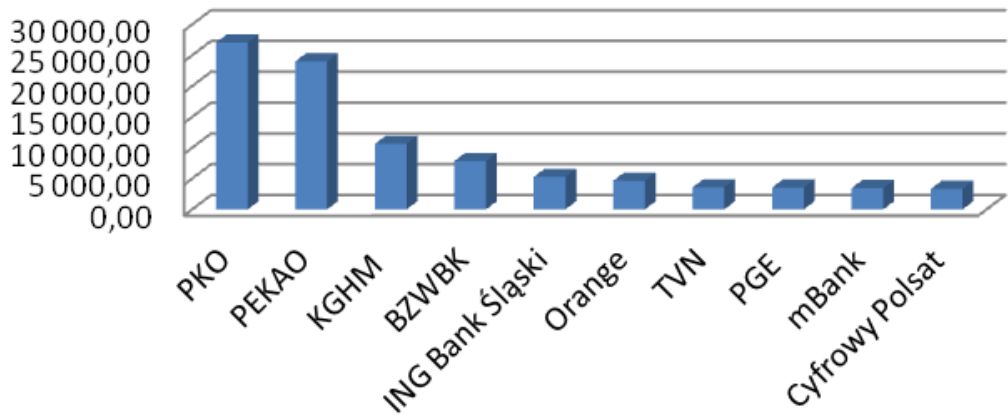

KI w 2010

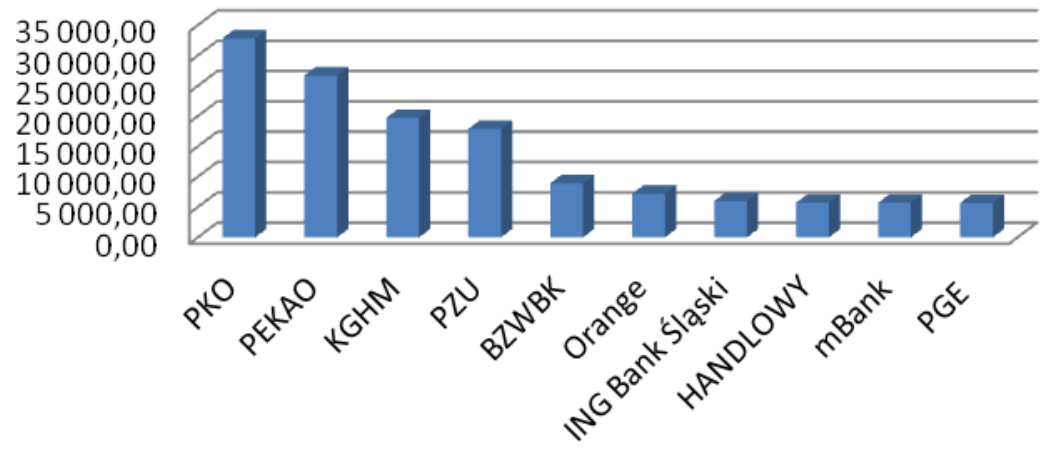




\section{KI w 2011}

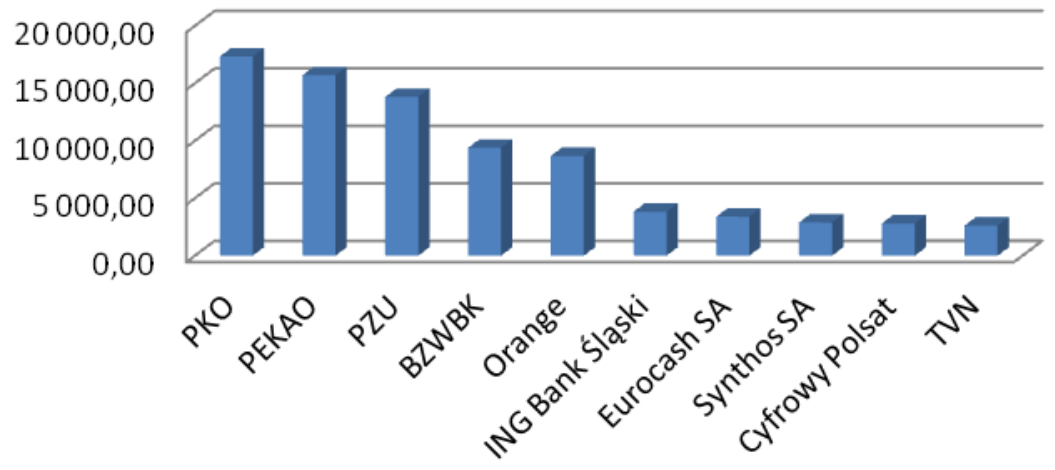

\section{KI w 2012}

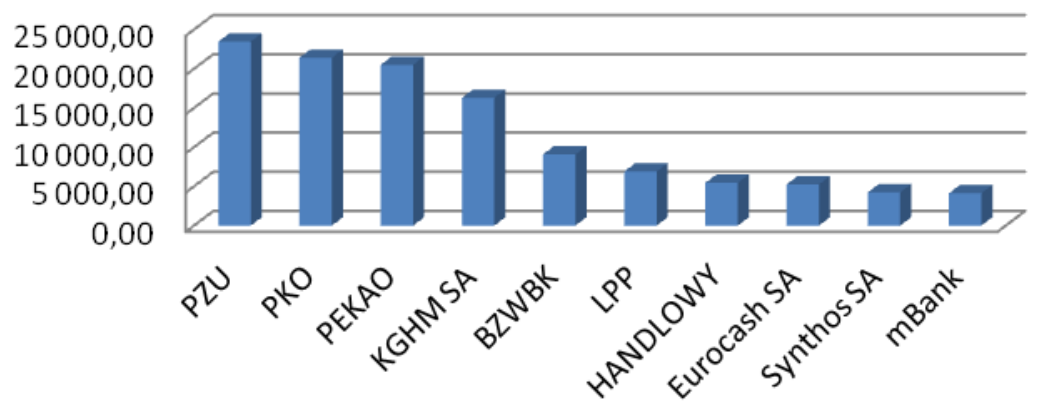

Źródło: opracowanie własne.

W badanym okresie banki PKO BP i PEKAO SA odnotowują najwyższe wartości kapitału intelektualnego. Analizując dynamikę zmian wartości dla tych przedsiębiorstw, można stwierdzić, że w 2010 r. nastąpił wzrost wartości kapitału intelektualnego tych przedsiębiorstw, natomiast w kolejnym roku jego wartość spadła prawie dwukrotnie. Należy podkreślić, iż rok 2011 był trudny dla uczestników giełdy i charakteryzował się wieloma spadkami. Były one w głównej mierze wynikiem kolejnej fali światowego kryzysu gospodarczego, co miało swoje odzwierciedlenia m.in. w spadkach cen akcji spółek notowanych na GPW. Zmiana trendu widoczna 
jest już w 2012 r., kiedy wartość kapitału intelektualnego banku PEKAO SA wzrosła o 31\%, a banku PKO BP o 24\%. Lider roku 2012 - PZU - również odnotował spadek kapitału intelektualnego w 2011, natomiast w 2012 osiągną wartość o 70\% wyższą niż w roku poprzednim.

Na uwagę zasługuje fakt, że wśród dziesięciu spółek o najwyższym kapitale intelektualnym rzadko występują przedsiębiorstwa przemysłowe, co potwierdza hipotezę, że tego typu podmioty budują swoją wartość na majątku materialnym. W badanym okresie przedsiębiorstwem przemysłowym o najwyższym kapitale intelektualnym była spółka KGHM Polska Miedź SA (przemysł surowcowy). Przedsiębiorstwo to osiąga wysokie wartości kapitału intelektualnego, jedynie w 2011 r. generuje wartość ujemną, co jest przede wszystkim wynikiem 35-procentowego spadku cen akcji tego przedsiębiorstwa. Drugą firmą przemysłową o najwyższym kapitale intelektualnym jest spółka Synthos SA (przemysł chemiczny), która co prawda w 2009 r. osiąga ujemną wartość, natomiast od 2010 wartość kapitału intelektualnego tego przedsiębiorstwa z roku na rok wzrasta.

W przeprowadzonym badaniu oprócz wyliczenia wartości kapitału intelektualnego obliczono również, jaki jest udział kapitału intelektualnego w generowaniu wartości rynkowej przedsiębiorstwa. Wyniki przedsiębiorstw osiągających najwyższe wartości tego wskaźnika przedstawia tabela 2.

Tabela 2. Spółki o najwyższym udziale kapitału intelektualnego w wartości rynkowej

\begin{tabular}{lcccc}
\hline \multicolumn{1}{c}{ Spółka } & 2009 & 2010 & 2011 & 2012 \\
\hline & & $\%$ & & \\
Eurocash & 83,53 & 87,11 & 86,08 & 87,01 \\
CCC & 81,77 & 83,81 & 72,57 & 81,14 \\
LPP & 75,03 & 80,32 & 74,18 & 85,05 \\
Cyfrowy Polsat & 91,16 & 90,33 & 59,68 & 56,82 \\
TVN & 73,58 & 78,84 & 73,93 & 60,16 \\
BZWBK & 56,52 & 56,87 & 55,64 & 50,28 \\
HANDLOWY & 32,22 & 46,85 & 27,36 & 42,45 \\
PEKAO & 56,68 & 56,86 & 42,37 & 46,64 \\
PKO & 56,98 & 60,58 & 43,16 & 46,43 \\
ING Bank Śląski & 51,91 & 51,45 & 37,34 & 31,29 \\
PZU & & 58,30 & 51,77 & 62,19 \\
\hline
\end{tabular}


Na podstawie przeprowadzonych wyliczeń nasuwa się wniosek, iż w przedsiębiorstwach zajmujących się handlem (Eurocash, CCC, LPP) oraz mediami (Cyfrowy Polsat, TVN) wartość rynkowa generowana jest przede wszystkim przez posiadany kapitał intelektualny. W spółkach handlowych średnio ponad 80\% wartości rynkowej budowana jest przez zasoby niematerialne. W spółkach z sektora mediów w pierwszych dwóch latach Cyfrowy Polsat osiągał wartości tego wskaźnika powyżej 90\%, a TVN ponad 70\%. Natomiast w latach 2011 i 2012 spółki te odnotowują spadek do poziomu odpowiednio 60\% i 57\% dla Cyfrowego Polsatu oraz 74\% i 60\% dla TVN. Kolejną grupą przedsiębiorstw charakteryzujących się wysokim udziałem kapitału intelektualnego w generowaniu wartości rynkowej są spółki finansowe: banki i spółka ubezpieczeniowa. Średnio osiągane przez te przedsiębiorstwa wartości kształtują się na poziomie $50 \%$.

Należy podkreślić, że w roku 2011 wartość wskaźnika przedsiębiorstw przedstawionych w tabeli 2 uległa spadkowi. Jak już wcześniej wspomniano, spadki prezentowanych wartości mają swoje źródło w spadku cen akcji w tym okresie w wyniku przede wszystkim kryzysu na rynkach finansowych.

\section{Podsumowanie}

W artykule zaprezentowano koncepcję pomiaru wartości kapitału intelektualnego w wyniku określenia różnicy między wartością rynkową a wartością księgową trzydziestu największych przedsiębiorstw notowanych na warszawskiej Giełdzie Papierów Wartościowych. Wśród badanych przedsiębiorstw 17 spółek w badanym okresie 2009-2012 osiąga dodatnie wartości, co oznacza, że wartość rynkowa tych przedsiębiorstw jest wyższa od wartości księgowej. Innymi słowy oznacza to, że inwestorzy są skłonni zapłacić za te przedsiębiorstwa więcej, niż stanowi wartość ich majątku materialnego. Tym samym oznacza to, że wartość rynkowa generowana jest przez zasoby o charakterze niematerialnym - kapitał intelektualny.

Przedsiębiorstwa o najwyższej wartości kapitału intelektualnego pochodzą przeważnie z sektora usług finansowych, a w badanym okresie liderami są banki PEKAO SA oraz PKO BP.

Analizując natomiast udział kapitału intelektualnego w kształtowaniu wartości rynkowej, należy stwierdzić, że najwyższe wyniki osiągają spółki handlowe - Eurocash, CCC, LPP oraz spółki zajmujące się mediami - Cyfrowy Polsat i TVN. 
W przypadku badanych przedsiębiorstw handlowych wartość tego wskaźnika kształtuje się średnio na poziomie $80 \% \mathrm{w}$ całym badanym okresie. W spółkach mediów najwyższe wartości osiągane były w 2009 i 2010, natomiast w 2011 i 2012 mimo wysokich wartości zauważalny jest spadek udziału wartości kapitału intelektualnego w generowaniu wartości rynkowej tych przedsiębiorstw.

Wśród badanych przedsiębiorstw największą grupę stanowiły banki (7 spółek). Wartość kapitału intelektualnego badanych banków jest bardzo zróżnicowana, co wynika przede wszystkim z różnicy w ich wielkości. Natomiast średnio we wszystkich badanych bankach udział kapitału intelektualnego w tworzeniu wartości rynkowej stanowi ponad $50 \%$.

Przeprowadzone badanie stanowi wstęp do analizy kapitału intelektualnego przedsiębiorstw notowanych na GPW. Uzyskane wyniki stanowią podstawę do przeprowadzenia kolejnych badań i analiz zarówno o charakterze ilościowym, jak jakościowym w zakresie kapitału intelektualnego. Wyniki z dalszych prac autorka prezentować będzie w kolejnych publikacjach naukowych.

\section{Literatura}

Beyer K., Problematyka pomiaru kapitalu intelektualnego, w: Wycena przedsiębiorstw, zarządzanie wartościa, zarządzanie ryzykiem, red. D. Zarzecki, Zeszyty Naukowe Uniwersytetu Szczecińskiego 2013, nr 761, „Finanse. Rynki Finansowe. Ubezpieczenia” nr 60.

Bukh P.N., Larsen H.T., Mouritsen J., Constructing Intellectual Capital Statements, „Scandinavian Journal of Management" 2001, No. 17.

Edvinsson L., Malone M.S., Kapitat intelektualny, Wydawnictwo Naukowe PWN, Warszawa 2001.

Fruin W.M., Knowledge Works: Managing in Intellectual Capital at Toshiba, Oxford University Press, New York 1997.

Kasiewicz S., Rogowski W., Kicińska M., Kapitat intelektualny, spojrzenie z perspektywy interesariuszy, Oficyna Ekonomiczna, Kraków 2006.

Sveiby K.E., Methods for Measuring Intangible Assets, www.sveiby.com/articles/IntangibleMethods.htm (8.02.2014). 


\title{
THE VALUE OF INTELLECTUAL CAPITAL OF COMPANIES LISTED ON WIG30
}

\begin{abstract}
The purpose of this article is to present the results of measuring the intellectual capital of companies listed on the Warsaw Stock Exchange on the WIG30 Index in the period 2009 -2012. The value of the intellectual capital of the companies was determined by use of the concept which defines intellectual capital as the difference between the market value and the book value of the company. Presented results are the part of research project entitled "Shaping the resources of intellectual capital in enterprises" which was founded by the National Science Centre allocated on the basis of the decision DEC-2011/01/N/HS4/06036.

The measurement of intellectual capital is an extremely important task for today's companies. This measurement is needed to manage intellectual capital, whose resources are key factors of the business success. The measurement presented in this article allows to compare the value of intellectual capital between the companies and provides a tool to monitor the ongoing trends of its value over time.
\end{abstract}

Translated by Karolina Beyer

Keywords: Intellectual capital, intellectual capital valuation, Market Value to Book Value, WIG30

JEL Codes: D24, M19, M49 